\title{
INFLUENCE OF 1-METHYLCYCLOPROPENE AND ULO CONDITIONS ON SENSORY CHARACTERISTICS OF APPLE FRUIT GROWN IN LATVIA
}

\author{
Karina JUHN̦EVIČA-RADENKOVA*, Vitalijs RADENKOVS \\ Institute of Horticulture, Latvia University of Agriculture \\ Graudu Str. 1, LV-3701 Dobele, Latvia
}

Received: March 2016; Accepted: June 2016

\begin{abstract}
The aim of the study was to evaluate the influence of 1-methylcyclopropene (1-MCP) treatment and ultra-low oxygen (ULO) storage conditions on the sensory characteristics of apples. Two apple storage technologies were tested in this study: cold storage under traditional conditions in combination with 1-MCP treatment, and ULO storage with two different compositions of a gas mixture. Apples were stored for 6 months. After storage, the sensory characteristics were analysed. Sensory evaluation showed that storage technology affected the sensory characteristics and panelists' acceptability. Distinctive differences were found between apples stored under controlled atmosphere and traditional conditions. Trained panelists highlighted that samples stored under controlled atmosphere had pronounced juiciness and color, while 1MCP-treated apples stored in cold were sweeter and more aromatic. Apples of the autumn cultivar 'Auksis', was perceived considerably higher after harvest and before long-term storage, compared with other cultivars. During 6 months of storage in controlled atmosphere, the sensory quality of these apples remained intact. Also, the sensory quality of fruit of the winter cultivar 'Sinap Orlovskij' throughout 6 months of its storage in controlled atmosphere remained intact. Besides, it was noticed that apples stored in controlled atmosphere were juicier and more aromatic with intense color. There is a positive effect of 1-MCP treatment on maintenance of apple quality stored in normal atmosphere for 6 months. With regard to some quality parameters and sensory attributes, 1-MCP-treated apples stored under normal atmosphere are comparable to those stored under ULO conditions.
\end{abstract}

Key words: apple fruit, controlled atmosphere, 1-methylcyclopropene (1-MCP) treatment, sensory evaluation

\section{INTRODUCTION}

The apple fruit quality is usually characterized by the appearance, size, shape and skin color (Rutkowski et al. 2008). Cultivar, type of rootstock, soil and fertigation management and irrigation regime play a significant role in determining the preand post-harvest fruit quality (Kühn et al. 2011).

However, the main qualitative indicators of fruits are firmness and aroma (Awad \& De Jager 2003; Aaby et al. 2002), and sweetness (Galmarini et al. 2012). According to Milosevics et al. (2009), consumers' choice (eating quality) of apples is determined by aroma, taste and firmness.
Sugars, organic acids and phenols are the crucial compounds that determine the formation of fruit aroma through metabolic processes during ripening, harvest and post-harvest storage of apples, and are particularly affected by cultivar and storage technology (Ackermann et al. 1992; Boylston et al. 1994).

Storage under controlled atmosphere suppresses the degenerative processes that trigger the senescence of fruit, resulting in extension of storage duration. However, storage in controlled atmosphere can significantly suppress the formation of volatile compounds, particularly those responsible for formation of a desirable aroma in apples, resulting in a decrease in the sensory quality of apples (Boylston et al. 1994; Brackmann et al. 1994). 
According to Raffo et al. (2009), the shelf-life of apples can be extended using controlled atmosphere storage; however, this technology and ultra low oxygen (ULO) can suppress the production of aroma compounds, a key contributor to the flavour of apples. Ciesa et al. (2013) indicated that ULO technology alters the production of volatile organic compounds (VOCs), which, among others, are important for aroma attributes. Hence, this storage technology impairs the sensory aspects of fruits.

Kruczyńska and Rutkowski (2006) reported that firmness, soluble solids, and total acid content of the cultivars 'Rajka', 'Rubinola' and 'Topaz' fruit, did not differ significantly as a result of storage in normal or controlled atmosphere.

Synthetic regulator 1-methylcyclopropene (1-MCP) has been shown to bind to the ethylene receptors and prevent the physiological action of ethylene (Sisler et al. 1996; Sisler \& Serek 1997). Several apple cultivars have been tested for their responses to 1-MCP, and in all cases, 1-MCP was found to delay softening and loss of acidity, and decrease ethylene production. Important factors concerning the efficacy of 1-MCP treatment are: 1) its concentration, time and temperature dependency; 2) the concentration required to inhibit ripening varies with the type of fruit and the stage of ripening at the time of treatment; and 3) although common opinion accepts that 1-MCP binding to the ethylene receptor is irreversible, Blankenship and Dole (2003) and Pre-Aymard et al. (2005) reported the regeneration of binding receptors in some flowers and tomato fruit, which can render 1-MCP treatment ineffective. Although 1MCP is very effective as a tool to maintain fruit quality, during long-term storage, the inhibition of the physiological action of ethylene makes apples more difficult to ripen, which adversely influences the sensory quality of the fruits (Calvo 2010).

The aim of the study was to evaluate the influence of 1-MCP treatment and ULO storage conditions on the sensory characteristics of apples.

\section{MATERIALS AND METHODS}

The study was carried out for two successive storage seasons (2012/2013 and 2013/2014) at the
Experimental Processing Department of the Latvia State Institute of Fruit-Growing (currently the Institute of Horticulture, Latvia University of Agriculture) in Dobele. The analyses of apples during each season were performed at harvest and after 6 months of storage.

The following apple cultivars were chosen for the experiment - autumn cultivars: 'Auksis', 'Orlik', 'Gita'; and winter cultivars: 'Antej', 'Belorusskoje Malılinovoje', 'Sinap Orlovskij' and 'Zarja Alatau'. All apple trees were grafted on the rootstock B9 and grown under the same conditions in the orchard run in an integrated system. Plants were treated twice a year with $6 \mathrm{~kg} \cdot \mathrm{ha}^{-1} \mathrm{CaCl}_{2}$. In the first season, the first application was carried out on July 17 , and the second on July 29 ; and in 2013 , the first application was carried out on July 13, and the second on August 1. In both seasons, the apples were harvested twice within an interval of 4-6 days. Ripening stage of the fruit was assessed by starch index using the starch iodine test and Streif index (SI) $\mathrm{F} /(\mathrm{R} \times \mathrm{S})$ (Streif 1996), where $\mathrm{F}$ is the firmness in $\mathrm{kg} \cdot \mathrm{cm}^{-2}, \mathrm{R}$ the soluble solid content (TSS) in ${ }^{\circ} \mathrm{Bx}$, and $S$ is the starch index (on a scale from 1 to 10). The harvested fruits met the requirements for fruits intended for long-term storage in Latvia (Drudze 2003; 2006)

Shortly after harvesting, the apples were aircooled for $24 \mathrm{~h}$ in a cooling chamber at $4{ }^{\circ} \mathrm{C} \pm$ $0.5^{\circ} \mathrm{C}$. Forty fruits (about $6 \mathrm{~kg}$ ) were sampled per cultivar per treatment per storage technology. Then the samples were placed in polypropylene boxes with perforated walls. The cooled apples were divided into four groups for post-harvest storage: 1) cold storage - control, apples were stored under normal atmosphere (air) conditions - called 'cold storage conditions' (CS); 2) cold storage +1 -MCPtreated apples stored in air - called 'cold storage + 1-MCP treatment' (CS_1-MCP); 3) ULO1 - $\mathrm{CO}_{2}$ $2 \%, \mathrm{O}_{2} 1 \%$; and 4) $\mathrm{ULO} 2-\mathrm{CO}_{2} 2.5 \%, \mathrm{O}_{2} 1.5 \%$. For ULO storage Fruit Control Equipment s.r. 1., $\mathrm{FC}_{\mathrm{E}}$ Industry, (Triulzi, Italy). All samples were stored at a temperature of $+2{ }^{\circ} \mathrm{C} \pm 1{ }^{\circ} \mathrm{C}$ and relative air humidity of $85 \%$. Treatment with ethylene inhibitor 1MCP (purchased from Rohm and Haas Company, Milan, Italy) was performed in an airtight fruit processing container. 
SmartFresh ${ }^{\mathrm{TM}}$, a powdery substance releasing 1-MCP, was dissolved in warm water at $+50{ }^{\circ} \mathrm{C} \pm 2{ }^{\circ} \mathrm{C}$ in a ratio of $1: 30$ to a concentration $0.625 \mu 1 \cdot \mathrm{dm}^{-3}$, according to Wawrzyńczak et al. (2007). Treatment with 1-MCP was performed at a temperature of $4{ }^{\circ} \mathrm{C}$ $\pm 0.5^{\circ} \mathrm{C}$ in a gas-tight container for $24 \mathrm{~h}$. After treatment, the fruit samples were stored in cold storage under normal atmosphere conditions.

\section{Physical and chemical analyses}

Flesh firmness was measured on two opposite sides of each apple fruit using a digital penetrometer (model TR 53205, Italy) equipped with an $11 \mathrm{~mm}$ diameter probe; the results were expressed in $\mathrm{kg} \cdot \mathrm{cm}^{-2}$.

Titratable acidity (TA) was determined using the standard method LVS EN 12147:2001 and quantified by titration of $1 \mathrm{ml}$ of juice (automatic titration DL 21; Mettler Toledo, Greifensee, Switzerland) with $0.1 \mathrm{M} \mathrm{NaOH}$ to an end point at $\mathrm{pH}$ 8.1; the expended amount of $\mathrm{NaOH}$ was expressed as the percentage of malic acid.

TSS was determined using the standard method LVS EN 12143:2001. Ten fruits of each cultivar were selected and processed with a hand blender Bamix ${ }^{\circledR}$ (Switzerland), into puree, for which the content of soluble solids (in ${ }^{\circ} \mathrm{Bx}$ ) was determined using a digital electronic refractometer (type Pal-1, ATAGO, Tokyo, Japan). TSS/TA ratio was also calculated as the quality index.

Starch iodine test is based on the reaction of iodine with starch and is expressed by specific blue coloring. During comparison, only the sizes and proportions of the colored field were evaluated, but not the coloration intensity or the color tone. The standard scale range is 1-10 points, where 1 indicates clear blue (unripe apples) and 10 denotes the starch has broken up and the apple remains untangled (López-Camelo 2004). An immature apple will have a relatively high amount of starch and will stain blue. As the fruit matures, it will show less blue staining, as the starch gets converted into sugar.

\section{Sensory evaluation}

Fifteen well-trained panelists ( 5 men and 10 women), aged between 25 and 50, participated in the current study. The sensory attributes of apples were evaluated using Line scale evaluation accord- ing to the standard method ISO 4121:2003 - Sensory analysis - Guidelines for the use of quantitative response scales. Each sample was coded randomly with three digit numbers to reduce any possible bias. The panelists were provided with five slices of apples from every experimental sample and asked to score them for different sensory attributes. To avoid unwanted browning, the apples were cut just before being served and placed on each serving tray in a randomized order. To evaluate the overall acceptability of the apple (external quality), whole uncut apple sample was also provided with the slices. To evaluate the sensory attributes such as color, aroma, taste, acidity, sweetness and juiciness, all apple samples were assessed using a 12-point Line scale, where 12 denotes 'like extremely,' 6 denotes 'neither like nor dislike' and 0 denotes 'dislike extremely.'

\section{Statistical analysis}

Data analysis was carried out using the General Linear Model functions in the IBM ${ }^{\circledR}$ SPSS ${ }^{\circledR}$ statistical programme 20.0 (SPSS Inc., Chicago, IL, USA) and Microsoft Office Excel 2007 (Redmond, WA, USA). The obtained data were analysed using descriptive statistics. Significant differences were determined by Least Significant Difference criteria. Mean and standard deviation values were calculated for all parameters.

In order to compare sensory characters, data obtained using Line scale, were processed by PanelCheck V1.4.2 programmed by Oliver Tomic and Henning Risvik software using principal component analysis (Næs et al. 2010).

\section{RESULTS AND DISCUSSION}

\section{Physical and chemical parameters at the time of harvest}

The aim of the current study was to evaluate the fruit quality based on the physical and chemical changes occurring within 6 months of storage under different conditions. Data presented in Tables 1 and 2 solely and only serve as the information to readers about the physical and chemical parameters at the time of harvesting. These data were used for calculation of SI. 
Table 1. Physical and chemical parameters of apples aimed to determine the optimal harvesting time

\begin{tabular}{|c|c|c|c|c|c|c|c|}
\hline \multirow{2}{*}{ Cv. } & \multirow[t]{2}{*}{$\begin{array}{l}\text { Harvest- } \\
\text { ing term }\end{array}$} & \multicolumn{2}{|c|}{ Firmness $\left(\mathrm{kg} \cdot \mathrm{cm}^{-2}\right)$} & \multicolumn{2}{|c|}{ Soluble solids content $\left({ }^{\circ} \mathrm{Bx}\right)$} & \multicolumn{2}{|c|}{ Total acid content $(\%)$} \\
\hline & & 2012 & 2013 & 2012 & 2013 & 2012 & 2013 \\
\hline \multicolumn{8}{|c|}{ Autumn cultivars } \\
\hline \multirow{2}{*}{ A } & 1 & $9.40^{\mathrm{a}} \pm 1.92$ & $6.45^{\mathrm{b}} \pm 0.23$ & $11.27^{\mathrm{a}} \pm 0.18$ & $11.60^{\mathrm{a}} \pm 0.12$ & $0.62^{\mathrm{a}} \pm 0.03$ & $0.84^{\mathrm{a}} \pm 0.01$ \\
\hline & 2 & $6.55^{\mathrm{b}} \pm 0.78$ & $6.23^{\mathrm{b}} \pm 0.54$ & $11.57^{\mathrm{a}} \pm 0.33$ & $13.16^{\mathrm{b}} \pm 0.26$ & $0.47^{\mathrm{b}} \pm 0.01$ & $0.84^{\mathrm{a}} \pm 0.02$ \\
\hline \multirow{2}{*}{$\mathrm{O}$} & 1 & $8.49^{a} \pm 2.79$ & $6.40^{\mathrm{b}} \pm 0.23$ & $11.04^{\mathrm{a}} \pm 0.10$ & $12.44^{\mathrm{a}} \pm 0.16$ & $0.83^{\mathrm{c}} \pm 0.04$ & $0.84^{\mathrm{a}} \pm 0.03$ \\
\hline & 2 & $5.00^{\mathrm{b}} \pm 0.45$ & $6.09^{b} \pm 0.60$ & $11.26^{\mathrm{a}} \pm 0.29$ & $12.97^{\mathrm{b}} \pm 0.11$ & $0.48^{\mathrm{b}} \pm 0.00$ & $0.63^{\mathrm{b}} \pm 0.05$ \\
\hline \multirow{2}{*}{ G } & 1 & $6.07^{\mathrm{b}} \pm 0.64$ & $6.46^{\mathrm{b}} \pm 0.48$ & $10.44^{\mathrm{a}} \pm 0.14$ & $12.65^{\mathrm{b}} \pm 0.16$ & $0.95^{\mathrm{c}} \pm 0.04$ & $1.31^{\mathrm{c}} \pm 0.05$ \\
\hline & 2 & $5.34^{\mathrm{b}} \pm 0.47$ & $6.9^{\mathrm{b}} \pm 1.06$ & $10.75^{\mathrm{a}} \pm 0.25$ & $13.68^{\mathrm{b}} \pm 0.12$ & $0.75^{\mathrm{ac}} \pm 0.02$ & $1.18^{\mathrm{c}} \pm 0.00$ \\
\hline \multicolumn{8}{|c|}{ Winter cultivars } \\
\hline \multirow{2}{*}{ AN } & 1 & $6.44^{\mathrm{b}} \pm 0.64$ & $7.14^{\mathrm{b}} \pm 0.46$ & $11.14^{\mathrm{a}} \pm 0.17$ & $10.87^{a} \pm 0.16$ & $0.66^{\mathrm{a}} \pm 0.03$ & $1.17^{\mathrm{c}} \pm 0.00$ \\
\hline & 2 & $6.32^{\mathrm{b}} \pm 0.94$ & $6.72^{\mathrm{b}} \pm 0.51$ & $11.57^{\mathrm{a}} \pm 0.07$ & $13.72^{\mathrm{b}} \pm 0.11$ & $0.66^{\mathrm{a}} \pm 0.01$ & $0.87^{a} \pm 0.00$ \\
\hline \multirow{2}{*}{$\mathrm{BM}$} & 1 & $8.64^{\mathrm{a}} \pm 1.27$ & $6.87^{\mathrm{b}} \pm 0.46$ & $9.26^{\mathrm{b}} \pm 0.27$ & $10.53^{a} \pm 0.19$ & $0.81^{\mathrm{c}} \pm 0.04$ & $0.98^{\mathrm{ac}} \pm 0.04$ \\
\hline & 2 & $6.77^{\mathrm{b}} \pm 1.42$ & $6.56^{\mathrm{b}} \pm 0.60$ & $10.18^{\mathrm{b}} \pm 0.24$ & $11.19^{a} \pm 0.22$ & $0.75^{\mathrm{ac}} \pm 0.03$ & $1.09^{\mathrm{ac}} \pm 0.00$ \\
\hline \multirow{2}{*}{ SO } & 1 & $8.81^{a} \pm 1.19$ & $8.14^{\mathrm{a}} \pm 1.32$ & $11.12^{\mathrm{a}} \pm 0.14$ & $10.48^{a} \pm 0.08$ & $0.82^{\mathrm{c}} \pm 0.03$ & $1.09^{\mathrm{ac}} \pm 0.00$ \\
\hline & 2 & $8.64^{\mathrm{a}} \pm 1.33$ & $7.64^{b} \pm 0.64$ & $11.84^{\mathrm{a}} \pm 0.17$ & $10.52^{\mathrm{a}} \pm 0.14$ & $0.77^{\mathrm{ac}} \pm 0.02$ & $1.13^{\mathrm{ac}} \pm 0.00$ \\
\hline \multirow{2}{*}{$\mathrm{ZA}$} & 1 & $6.92^{b} \pm 0.63$ & $7.17^{b} \pm 0.83$ & $12.08^{\mathrm{a}} \pm 0.35$ & $11.75^{\mathrm{a}} \pm 0.08$ & $0.68^{\mathrm{a}} \pm 0.01$ & $1.06^{\mathrm{ac}} \pm 0.04$ \\
\hline & 2 & $6.05^{\mathrm{b}} \pm 0.94$ & $6.43^{b} \pm 0.55$ & $12.40^{\mathrm{a}} \pm 0.23$ & $12.35^{\mathrm{b}} \pm 0.05$ & $0.65^{\mathrm{a}} \pm 0.01$ & $1.09^{\mathrm{ac}} \pm 0.08$ \\
\hline
\end{tabular}

Notes: Cultivars: A - 'Auksis'; O - 'Orl̦ik’; G - 'Gita'; AN - ‘Antej’; BM - 'Belorusskoje Malinovoje'; SO - 'Sinap Orlovskij'; ZA - 'Zarja Alatau'

The different letters in the same column represent significant differences between mean values with standard deviation $( \pm$ ) by the LSD at the 0.05 level.

Table 2. The parameters characterizing the maturity stage of apples

\begin{tabular}{|c|c|c|c|c|c|c|c|}
\hline \multirow{2}{*}{ Cultivar } & \multirow{2}{*}{$\begin{array}{l}\text { Harvest- } \\
\text { ing time }\end{array}$} & \multicolumn{2}{|c|}{ Harvesting date } & \multicolumn{2}{|c|}{ Iodine-starch test (1-10) } & \multicolumn{2}{|c|}{ Streif index } \\
\hline & & 2012 & 2013 & 2012 & 2013 & 2012 & 2013 \\
\hline \multicolumn{8}{|c|}{ Autumn cultivars } \\
\hline \multirow{2}{*}{ A } & 1 & $06 / 09$ & $10 / 09$ & $5.00^{\mathrm{aA}}$ & $3.50^{\mathrm{aB}}$ & $0.16^{\mathrm{aA}}$ & $0.16^{\mathrm{aA}}$ \\
\hline & 2 & $11 / 09$ & $14 / 09$ & $5.50^{\mathrm{bA}}$ & $6.50^{\mathrm{bB}}$ & $0.10^{\mathrm{bA}}$ & $0.07^{\mathrm{bA}}$ \\
\hline \multirow{2}{*}{$\mathrm{O}$} & 1 & $06 / 09$ & $10 / 09$ & $4.00^{\mathrm{aA}}$ & $3.50^{\mathrm{aB}}$ & $0.19^{\mathrm{aA}}$ & $0.15^{\mathrm{aA}}$ \\
\hline & 2 & $11 / 09$ & $14 / 09$ & $4.50^{\mathrm{bA}}$ & $6.20^{\mathrm{bB}}$ & $0.09^{\mathrm{bA}}$ & $0.08^{\mathrm{bA}}$ \\
\hline \multirow{2}{*}{ G } & 1 & $06 / 09$ & $10 / 09$ & $5.00^{\mathrm{aA}}$ & $6.30^{\mathrm{aB}}$ & $0.11^{\mathrm{aA}}$ & $0.08^{\mathrm{aA}}$ \\
\hline & 2 & $11 / 09$ & $14 / 09$ & $5.40^{\mathrm{bA}}$ & $6.40^{\mathrm{aB}}$ & $0.12^{\mathrm{aA}}$ & $0.07^{\mathrm{aB}}$ \\
\hline \multicolumn{8}{|c|}{ Winter cultivar } \\
\hline \multirow{2}{*}{ AN } & 1 & $28 / 09$ & $14 / 09$ & $4.50^{\mathrm{aA}}$ & $6.10^{\mathrm{aB}}$ & $0.12^{\mathrm{aA}}$ & $0.11^{\mathrm{aA}}$ \\
\hline & 2 & $03 / 10$ & $21 / 09$ & $5.00^{\mathrm{bA}}$ & $7.00^{\mathrm{bB}}$ & $0.10^{\mathrm{aA}}$ & $0.07^{\mathrm{bA}}$ \\
\hline \multirow{2}{*}{$\mathrm{BM}$} & 1 & $28 / 09$ & $14 / 09$ & $5.00^{\mathrm{aA}}$ & $3.70^{\mathrm{aB}}$ & $0.18^{\mathrm{aA}}$ & $0.18^{\mathrm{aA}}$ \\
\hline & 2 & $03 / 10$ & $21 / 09$ & $5.00^{\mathrm{aA}}$ & $5.90^{\mathrm{bB}}$ & $0.13^{\mathrm{bA}}$ & $0.10^{\mathrm{bA}}$ \\
\hline \multirow{2}{*}{ SO } & 1 & $28 / 09$ & $21 / 09$ & $4.00^{\mathrm{aA}}$ & $4.00^{\mathrm{aA}}$ & $0.19^{\mathrm{aA}}$ & $0.19^{\mathrm{aA}}$ \\
\hline & 2 & $03 / 10$ & $26 / 09$ & $4.80^{\mathrm{bA}}$ & $4.30^{\mathrm{aB}}$ & $0.15^{\mathrm{bA}}$ & $0.17^{\mathrm{aA}}$ \\
\hline \multirow{2}{*}{$\mathrm{ZA}$} & 1 & $10 / 10$ & $26 / 09$ & $4.50^{\mathrm{aA}}$ & $4.30^{\mathrm{aA}}$ & $0.12^{\mathrm{aA}}$ & $0.14^{\mathrm{aA}}$ \\
\hline & 2 & $16 / 10$ & $02 / 10$ & $6.70^{\mathrm{bA}}$ & $6.60^{\mathrm{bA}}$ & $0.07^{\mathrm{bA}}$ & $0.08^{\mathrm{bA}}$ \\
\hline
\end{tabular}

Notes: Cultivars: A - 'Auksis'; O - 'Orl̦ik’; G - 'Gita'; AN - ‘Antej’; BM - 'Belorusskoje Malinovoje'; SO - 'Sinap Orlovskij'; ZA - 'Zarja Alatau'

Mean value with standard deviation $( \pm$ ) for the same cultivar and year followed by different small letters are significantly different by the LSD at 0.05 level (differences between harvesting time).

Mean value with standard deviation $( \pm$ ) for the same cultivar and time of harvesting followed by different capital letters are significantly different by the LSD at 0.05 level (differences between year).

Red color of the numbers presented in table means recommended value for apple harvesting that subsequently will be kept in cold storage according to Drudze (2003; 2005). 
The firmness of apples is dependent on the degree of ripeness, place of growth, weather conditions and cultivar. The firmness decreases during fruit ripening; therefore, for all cultivars, the highest firmness was observed before storage; storage technology significantly affects the firmness of the apples (Köpcke 2015).

In 2012, the firmness and SI of cultivar 'Auksis' differed significantly between the harvesting times $\left(40 \pm 1.92 \mathrm{~kg} \cdot \mathrm{cm}^{-2}\right.$ in the first and $6.55 \pm$ $0.78 \mathrm{~kg} \cdot \mathrm{cm}^{-2}$ in the second) before storage (Table 1), and the SI values were 0.16 and 0.10 (optimal values) (Table 2). In 2013, the firmness was equal during both harvesting times $(6.45 \pm 0.23$ in the first and $6.23 \pm 0.54 \mathrm{~kg} \cdot \mathrm{cm}^{-2}$ in the second), whereas the SI values were significantly different ( 0.16 and 0.07 ).

The content of soluble solids in the fruit of cultivar 'Auksis' before storage was almost equal for both harvesting times of 2012 (11.27 \pm 0.18 in the first and $11.57 \pm 0.33$ in the second $\left.{ }^{\circ} \mathrm{Bx}\right)$ and significantly different for $2013(11.60 \pm 0.12$ in the first and $13.16 \pm 0.26$ in the second ${ }^{\circ} \mathrm{Bx}$ ) (Table 1).

The main acids in apples are malic acid, citric acid and tartaric acid, and their levels depend on the cultivar and the degree of ripeness. During ripening, the level of acids in apples decreases due to the activity of endogenous enzymes. The total content of acids in cultivar 'Auksis' differed between the harvesting times $(0.62 \pm 0.01 \%$ in the first and $0.47 \pm$ $0.04 \%$ in the second) (Table 1). However, the total acid content in apples collected in the year 2013 was the same for both harvesting times $(0.84 \%)$.

The chemical composition of the fruit and the degree of ripeness define the optimal harvesting time. Inadequate harvesting time decreases the storage possibility and the quality of fruits. Unripe apples respire more intensively during storage, which causes substantial moisture loss or softening, whereas overripe fruits have poor quality and low nutritional value; they are also sensitive to low-temperature injuries $\left(+2{ }^{\circ} \mathrm{C}\right)$ and their storage time should be limited. Therefore, in this study, two mature stages of each apple cultivar were tested to optimize the harvesting protocol.

Drudze $(2003$; 2005) defined and recommended the harvesting parameters for keeping the apples in cold storage based on starch iodine test and Streif ripening index. According to RiekstinaDolge (2014) and Krasnova (2013), the optimal starch iodine test should be from 5 to 7 .

The SI value obtained for cultivar 'Auksis' showed that in both years of investigation, it was closest to the advised optimal value (0.16-0.10), with the exception of the results from the second harvesting time in the year $2013(0.07)$ (Table 2). The SI value of cultivars 'Orlik' and 'Gita' in both years of testing was closer to optimal value during the first harvesting time $(0.19-0.15$ and $0.12-0.07$, respectively). The maturity stage of winter cultivar 'Antej' corresponded to the optimal value of SI (0.12-0.10). The cultivar 'Belorusskoje Malinovoje' achieved the optimal value of SI during the second harvesting time in the year $2013(0.10)$. The SI value of cultivar 'Sinap Orlovskij' apples showed that it was closer to optimum during the first harvesting time (0.19). Apples of cultivar 'Zarja Alatau' had insignificant difference ( $p>0.05)$ in SI value between both study years and harvesting times; however, the index was closer to the optimal value during the second harvesting time $(0.08-0.07)$.

For cold storage in air, both with and without 1-MCP treatment, the recommended SI value for autumn apple cultivars was 0.07-0.12, whereas for apples stored in ULO, it was 0.08-0.19. For winter cultivars, the recommended SI value for the cold storage, both with and without 1-MCP treatment, was $0.07-0.17$, but for storage in ULO chambers, the SI value was 0.10-0.19.

\section{Sensory evaluation of apples using Line scale}

Principal component analysis was performed on the sensory data of the seven analysed apple cultivars that had been stored for a long term under different conditions (Fig. 1A - autumn cultivars; Fig. 1B - winter cultivars). PC1 and PC2 together explain 79 and $57 \%$ of the samples' variance, respectively. As can be seen in Figure 1A, clear separation (top left square) of cultivar 'Auksis' apples (A_B before storage) is observed and those samples are kept separate from other apple samples. These apple samples were characterized as fruits with the most pronounced juiciness. However, as can be seen, a clear separation was also achieved between samples stored under ULO conditions and those kept under cold storage conditions. 


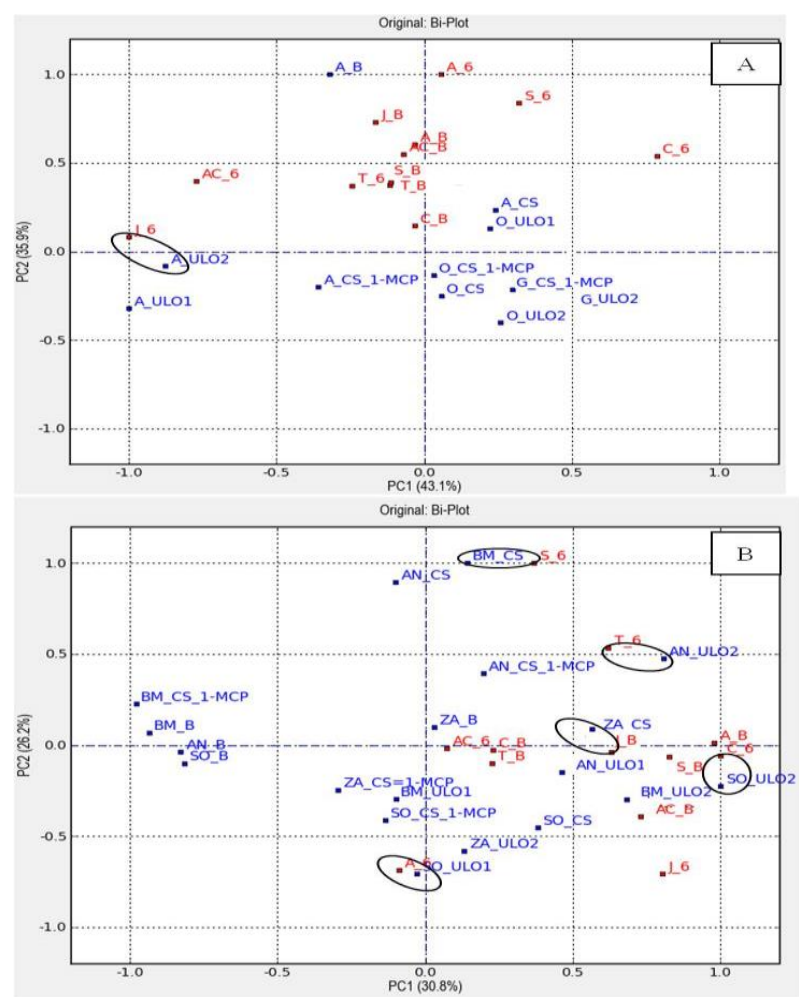

Fig. 1. Biplot presents the scores and loadings of the first two principal components of apple sensory data for the first harvesting time of the season 2012/2013 (A - autumn cultivars; $\mathrm{B}$ - winter cultivars)

Notes: Letters represented in the figures indicate the types of storage: $\mathrm{B}$ - before storage, $\mathrm{CS}$ - cold storage, CS_1-MCP - cold storage + 1-MCP treatment, ULO1 controlled atmospheric conditions 1 , ULO2 - controlled atmospheric conditions 2; Cultivars: A - 'Auksis', O 'Orl̦ik', G - 'Gita', AN - 'Antej', BM - 'Belorusskoje Maļinovoje', SO - 'Sinap Orlovskij', ZA - 'Zarja Alatau'; Attributes: C - color, A - aroma, T - taste, AC - acidity, S - sweetness, J - juiciness; capital letter B before storage, number 6 - after 6 months of storage.

ULO storage and 1-MCP treatment are located on the left side of the plot, but only samples stored for 6 months under ULO conditions were associated with distinctive juiciness. Moreover, fruits treated with 1-MCP did not have pronounced sensory attributes. Winter apple samples stored under ULO conditions had the most pronounced juiciness, while those kept for 6 months in cold storage as well as treated with 1-MCP only had a tendency to juiciness (AN_CS_1-MCP - Antej; ZA_CS - Zarja Alatau).

The apple samples that were kept under cold storage conditions for 6 months are located at the top of the plot - 'Belorusskoje Malinovoje' (Fig. 1B) - and were described as apples with the most

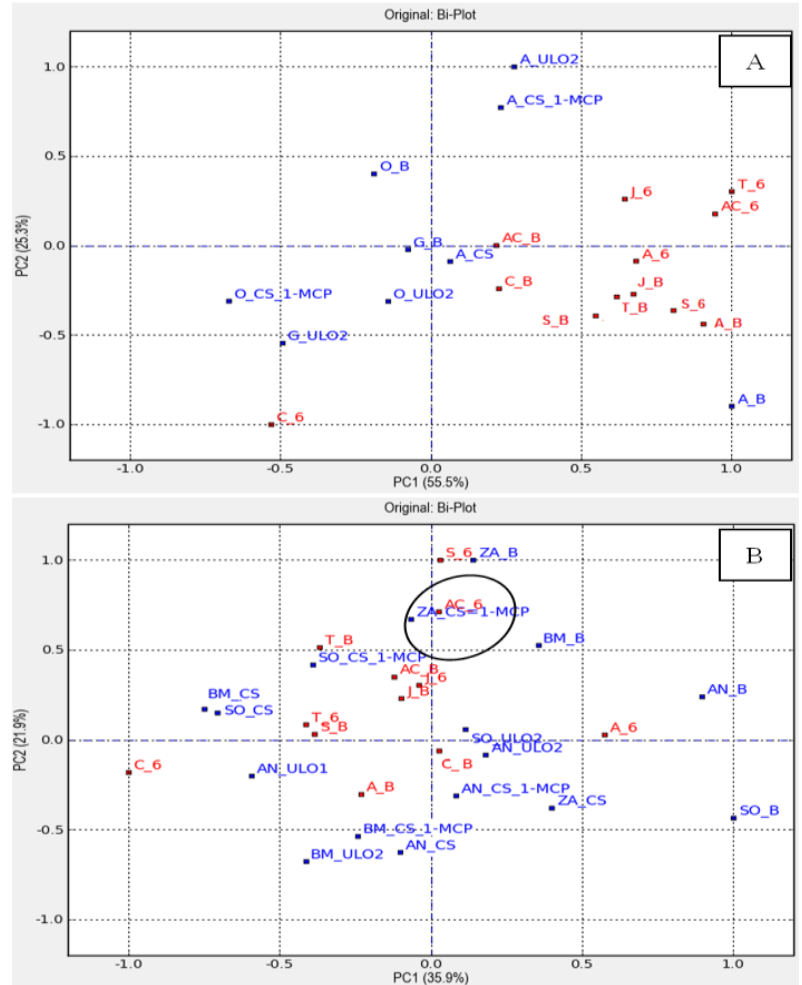

Fig. 2. Biplot presents the scores and loadings of the first two principal components of apple sensory data for the second harvesting time of the season 2012/2013. (A - autumn cultivars; $\mathrm{B}$ - winter cultivars)

Notes: Letters represented in the figures indicate the types of storage: $\mathrm{B}$ - before storage, CS - cold storage, CS_1-MCP - cold storage + 1-MCP treatment, ULO1 controlled atmospheric conditions $1, \mathrm{ULO} 2$ - controlled atmospheric conditions 2; Cultivars: A - 'Auksis', O 'Orlik', G - 'Gita', AN - 'Antej', BM - 'Belorusskoje Malıinovoje', SO - 'Sinap Orlovskij', ZA - 'Zarja Alatau'; Attributes: C - color, A - aroma, T - taste, AC - acidity, S - sweetness, J - juiciness; capital letter B before storage, number 6 - after 6 months of storage.

pronounced sweetness. Apples of cv. 'Antej' also had a tendency to achieve pronounced sweetness. Besides, right and on the bottom square located cluster disclosed that apple samples stored in ULO tended to be more acidic compared with other apple samples. Apple samples that were stored for 6 months in controlled atmosphere conditions in ULO1 and ULO2 (Fig. 1B) are located at the bottom of the plot, and they were highlighted by the panelists as samples with pronounced aroma (SO_ULO1) and color (SO_ULO2). Contradictory results were obtained by Raffo et al. (2009), who reported that apple storage in controlled modified atmosphere has both advantages and disadvantages. For instance, 
positive results were obtained with respect to shelflife prolongation. However, controlled atmosphere storage significantly affected the sensory qualities of the products. Authors revealed that this type of storage not only delayed the aging process, but also suppressed the synthesis of VOCs (esters, aldehydes, alcohols and terpenes), which are responsible for the development of fruit aroma.

Results depicted in Fig. 2A and B from second harvesting time of 2012 disclosed that PC1 and PC2 together explain 80.8 and $57.8 \%$ of the samples' variance, respectively. Also, a clear separation has been obtained here based on storage conditions. Apple samples stored under controlled atmosphere conditions in ULO2 are situated at a slight distance from those kept under cold storage conditions (Fig. 2A). Furthermore, apple samples that had been treated with 1-MCP before long-term storage are also located on the same cluster as ULO samples (left square, bottom). Based on the results obtained by PCA, it becomes evident that only those samples had a tendency to sweetness. Apple samples such as A_ULO2 and A_CS_1-MCP (situated on the top and right square of the plot) that were stored for 6 months tended to be more pronounced in juiciness, taste and acidity, compared with other apple samples.

Taking into consideration the results that were obtained from the first year of the study and the second harvesting time of winter apple cultivars, one can conclude that apples that were stored under ULO conditions are situated on the plot together with those that had been treated with 1-MCP (Fig. 2B). It should be noted that in all cases of storage, only those apple samples (AN_ULO1, BM_ULO2 and BM_CS_1-MCP) have a tendency to show a distinct color. Also, it has been highlighted by panelists that apple samples that had been treated with 1-MCP before long-term storage (ZA_CS_1MCP and SO_CS_1-MCP) had the most pronounced acidity (located on the top of the plot).

Based on the results that had been obtained in the second season (2013/2014) of the study (Fig. 3), it is evident that PC1 and PC2 together explain 89.9 and $57.3 \%$ of the samples' variance, respectively. Before storage, cultivar 'Auksis' had the highest scores among all apples and were located separately from the others (situated at the bottom of the plot in right square) (Fig. 3A).

Several reports focused on the aroma compound profile and evaluation of its synthesis, which depend on the post-harvest storage technologies and the treatment types the apples are subjected to. For instance, Marin et al. (2009) reported that 1-MCP significantly suppresses the synthesis of volatile compounds, which, among others, are important contributors to aroma formation. Defilippi et al. (2004) reported that dramatic inhibition of ethylene observed in fruits treated with 1-MCP caused remarkable reduction or delay in the accumulation of ester compounds, reaching a level of less than $10 \%$. Authors came to the conclusion that ester compound synthesis is regulated by ethylene in apples. In the current study, contradictory results have been obtained, which indicates that, before long-term storage, apples that were treated with 1-MCP (SO_CS_1-MCP) (located at the top of the plot in the right square) were sweeter and the most aromatic (Fig. 3B).

The same observation was made by Hoang et al. (2011) who suggested that, during fruit storage, the ripening processes (such as firmness, yellowing, respiration and ethylene production) can be delayed; therefore, fruits will be more aromatic and sweeter compared with untreated ones.

Panelists noted that apples of cultivars 'Sinap Orlovskij' (SO_ULO1) and 'Antej' (AN_ULO2) stored for 6 months under controlled atmosphere conditions in ULO1 and ULO2, as well as cultivars 'Sinap Orlovskij' (SO_CS) and 'Belorusskoje Maḷinovoje' (BM_CS), which had been kept in cold storage, were more juicy compared with other apple samples and storage technologies.

On evaluating the results obtained in the second season of the study from the second harvesting time (Fig. 4), it can be noted that PC1 and PC2 together explain 83.2 and $59.9 \%$ of the samples' variance, respectively. As can be seen in Figure 4A, a clear separation (top left square of the plot) of cultivar 'Auksis' samples (A_B - before storage) is observed from other samples. These apple samples had been characterized as fruits with the most pronounced sweetness. Furthermore, these apples had been characterized as fruits with distinctive taste, aroma and acidity. 


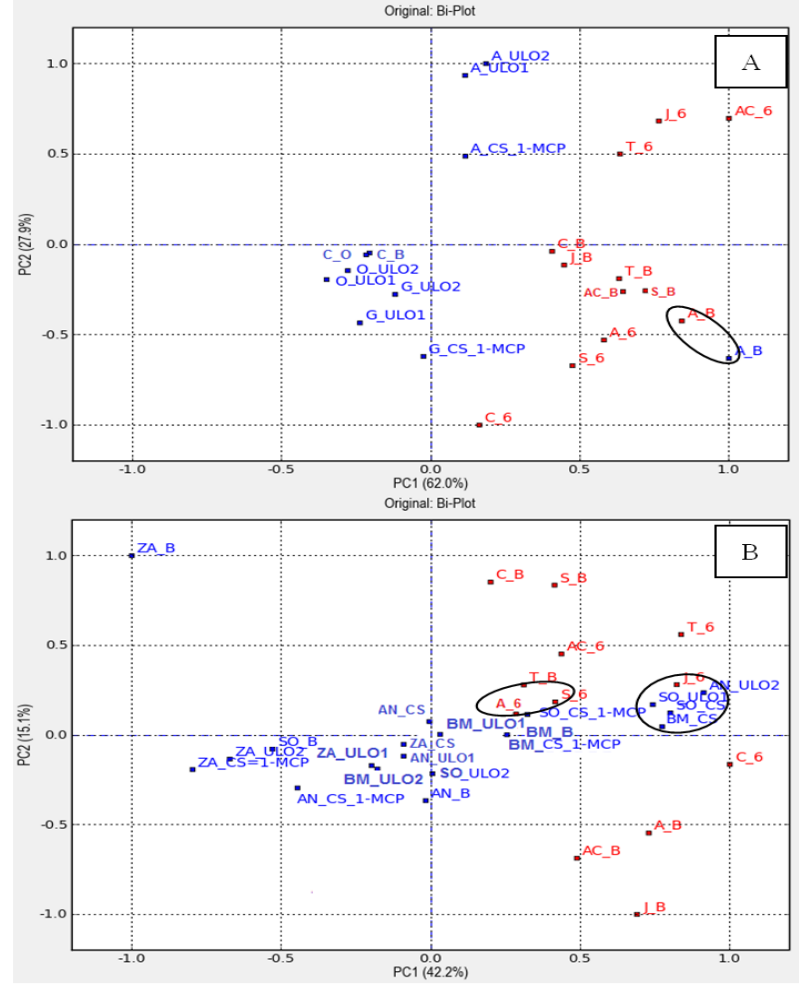

Fig. 3. Biplot presents the scores and loadings of the first two principal components of apple sensory data for the first harvesting time of the season 2013/2014. (A - autumn cultivars; $\mathrm{B}$ - winter cultivars)

Notes: Letters represented in the figures indicate the types of storage: B - before storage, CS - cold storage, CS_1-MCP - cold storage + 1-MCP treatment, ULO1 controlled atmospheric conditions $1, \mathrm{ULO} 2$ - controlled atmospheric conditions 2; Cultivars: A - 'Auksis', O 'Orlıik', G - 'Gita', AN - 'Antej', BM - 'Belorusskoje Maļinovoje', SO - 'Sinap Orlovskij’, ZA - 'Zarja Alatau'; Attributes: C - color, A - aroma, T - taste, AC - acidity, S - sweetness, J - juiciness; capital letter B before storage, number 6 - after 6 months of storage.

After 6 months of storage, cultivar 'Auksis' apples stored under controlled atmosphere conditions in ULO2, as well as those that before -storage had been treated with 1-MCP, had retained their taste, juiciness and acidity (situated at the bottom of the plot in center). The 'Orlik' samples that had been stored for 6 months under controlled atmosphere conditions in ULO1 were characterized as apples with the most pronounced sweetness and color (located at the top and center of the plot).

Evaluation of results obtained from second harvesting time showed that none of the samples had distinct sensory attributes before long-term storage (Fig. 4B). However, after 6 months of

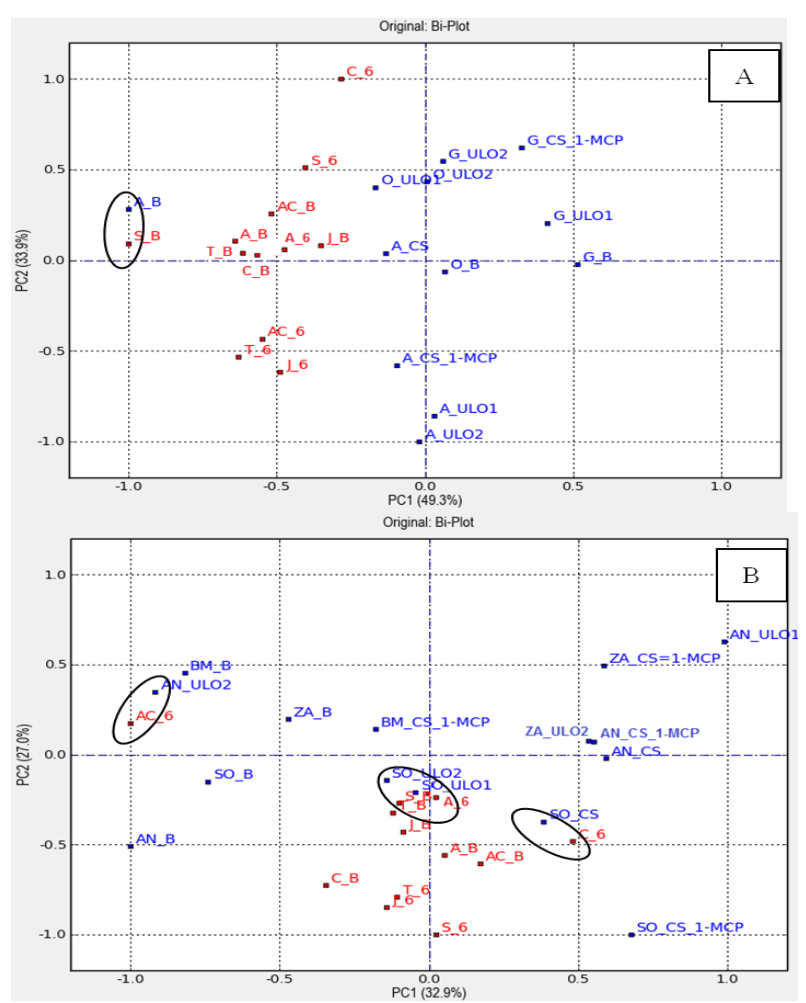

Fig. 4. Biplot presents the scores and loadings of the first two principal components of apple sensory data for the second harvesting time of the season 2013/2014. (A - autumn cultivars; $\mathrm{B}$ - winter cultivars).

Notes: Letters represented in the figures indicate the types of storage: B - before storage, CS - cold storage, CS_1-MCP - cold storage + 1-MCP treatment, ULO1 controlled atmospheric conditions $1, \mathrm{ULO} 2$ - controlled atmospheric conditions 2; Cultivars: A - 'Auksis', O 'Orlik', G - 'Gita', AN - 'Antej', BM - 'Belorusskoje Malıinovoje', SO - 'Sinap Orlovskij', ZA - 'Zarja Alatau'; Attributes: C - color, A - aroma, T - taste, AC - acidity, S - sweetness, J - juiciness; capital letter B before storage, number 6 - after 6 months of storage.

storage 'Sinap Orlovskij' apples (SO_CS) under cold storage conditions, they were characterized as samples with a distinctive color. Samples stored under controlled atmosphere conditions (AN_ULO2) were most acidic (SO_ULO1) and (SO_ULO2) more aromatic, but those before long-terms storage treated with 1-MCP - SO_CS_1-MCP - had a tendency to sweetness.

\section{CONCLUSION}

The present study shows that harvest time has an impact on the physical and chemical characteristics of apples (firmness, soluble solid content and 
TA). In accordance with the panelists' suggestions, even after 6 months of storage, fruits are sweeter and most aromatic, and have a tendency to develop juiciness and acidity. However, apple samples that had been stored under controlled atmosphere conditions (ULO1 and ULO2) were rated considerably higher, compared with 1-MCP-treated apples. Panelists noted that apple samples stored under controlled atmosphere conditions had pronounced juiciness, color, aroma and acidity. Among autumn cultivars, 'Auksis' apples before long-term storage were evaluated considerably higher compared with other cultivars. Moreover, during 6 months of storage in controlled atmosphere conditions, the sensory quality remained intact. Among winter cultivars, 'Sinap Orlovskij' apples throughout 6 months of storage in controlled atmosphere retained their sensory quality. Besides, it was noticed that these apples were juicier, more aromatic and had intensive color. There is a positive effect of 1-MCP treatment on maintenance of apple quality stored in normal atmosphere for 6 months. With regard to some quality parameters and sensory attributes, 1-MCPtreated apples stored under normal atmosphere are comparable to those stored under ULO conditions.

\section{Acknowledgements}

This research was carried out with funding from the State Research Programme "Sustainable use of local resources (earth, food, and transport) - new products and technologies (NatRes)" (2010-2014) project no. 3, "Sustainable use of local agricultural resources for development of high nutritive value food products (Food)" and the National Research Programme "Agricultural Resources for Sustainable Production of Qualitative and Healthy Foods in Latvia (AgroBioRes)" project no. 10-4/VPP-7/3.

\section{REFERENCES}

Aaby K., Haffner K, Skrede G. 2002. Aroma quality of Gravenstein apples influenced by regular and controlled atmosphere storage. Lebensmittel-Wissenschaft und -Technologie 35: 254-259. DOI: 10.1006/fstl.2001.0852.

Ackermann J., Fischer M., Amadò R. 1992. Changes in sugars, acids, and amino acids during ripening and storage of apples (cv. Glockenapfel). Journal of Agricultural and Food Chemistry 40: 1131-1134. DOI: 10.1021/jf00019a008.
Awad M.A., de Jager A. 2003. Influences of air and controlled atmosphere storage on the concentration of potentially healthful phenolics in apples and other fruits. Postharvest Biology and Technology 27: 5358. DOI: $10.1016 / \mathrm{S} 0925-5214(02) 00189-8$.

Blankenship S.M., Dole J.M. 2003. 1-Methylcyclopropene: a review. Postharvest Biology and Technology 28: 1-25. DOI: 10.1016/S0925-5214(02)00246-6.

Boylston T.D., Kupferman E.M., Foss J.D., Buering C. 1994. Sensory quality of Gala apples as influenced by controlled and regular atmosphere storage. Journal of Food Quality 17: 477-494. DOI: 10.1111/j.1745-4557.1994.tb00168.x.

Brackmann A., Streif J., Bangerth F. 1994. Influence of CA and ULO storage conditions on quality parameters and ripening of preclimactic and climacteric harvested apple fruits. I. Effect on colour, firmness, acidity, and solubles solids. Gartenbauwissenschaft 59(6): 252-257.

Calvo G. 2010. Antioxidant use in apple and pear storage. Part 3 - storage scald and 1-methlycyclopropene (1MCP). Postharvest Information Network, WSU Tree Fruit Research \& Extension Center, Washington State University. http://www.tfrec.wsu.edu/pdfs/P1609.pdf

Central Statistical Bureau. 2013. 2.4 thousand hectares of apple tree plantations are occupied by more than 1.3 million apple trees. Latvia. http://www.csb.gov.lv/notikumi/24-tukstosos-hektaru-abeldarzu-aug-vairak-neka13-miljoni-abelu-36541.html

Ciesa F., Dalla Via J., Wisthaler A., Zanella A., Guerra W., Mikoviny T. et al. 2013. Discrimination of four different postharvest treatments of 'Red Delicious' apples based on their volatile organic compound (VOC) emissions during shelf-life measured by proton transfer reaction mass spectrometry (PTRMS). Postharvest Biology and Technology 86: 329336. DOI: 10.1016/j.postharvbio.2013.06.036.

Defilippi B.G., Dandekar A.M., Kader A.A. 2004. Impact of suppression of ethylene action or biosynthesis on flavor metabolites in apple (Malus domestica Borkh) fruits. Journal of Agricultural and Food Chemistry 52: 5694-5701. DOI: 10.1021/jf049504x.

Drudze I. 2003. Investigations of harvest maturity and suitability for storage of some apple cultivars in Latvia. Acta Horticulturae 599: 631-637. DOI: 10.17660/ActaHortic.2003.599.82.

Drudze I. 2005. Harvest maturity and storage life investigations on Latvian apple cultivars. Latvian Journal of Agronomy 8: 306-310.

Galmarini M.V., Symoneaux R., Chollet S., Zamora M.C. 2013. Understanding apple consumers' expectations in terms of likes and dislikes. Use of 
comment analysis in a cross-cultural study. Appetite 62: 27-36. DOI: 10.1016/j.appet.2012.11.006.

Hoang N.T.T., Golding J.B., Wilkes M.A. 2011. The effect of postharvest 1-MCP treatment and storage atmosphere on 'Cripps Pink' apple phenolics and antioxidant activity. Food Chemistry 127(3): 12491256. DOI: 10.1016/j.foodchem.2011.01.052.

Köpcke D. 2015. 1-Methylcyclopropene (1-MCP) and dynamic controlled atmosphere (DCA) applications under elevated storage temperatures: effects on fruit quality of 'Elstar', 'Jonagold' and 'Gloster' apple (Malus domestica Borkh.). European Journal of Horticultural Science 80: 25-32. DOI: 10.17660/eJHS.2015/80.1.4

Krasnova I. 2013. Evaluation of quality influencing factors of fresh fruit salads. Doctoral thesis, Latvia University of Agriculture, Jelgava, Latvia, p. 206.

Kruczyńska D.E., Rutkowski K.P. 2006. Quality and storage of Czech scab resistant apple cultivars. Phytopathologia Polonica 39: 53-61.

Kühn B.F., Bertelsen M., Sørensen L. 2011. Optimising quality-parameters of apple cv. 'Pigeon' by adjustment of nitrogen._Scientia Horticulturae 129: 369375. DOI: 10.1016/j.scienta.2011.03.033.

López Camelo A.F. 2004. Manual for the preparation and sale of fruits and vegetables. From field to market. FAO Agricultural Services Bulletin 151: 11-26.

Lurie S., Pre-Aymard C., Ravid U., Larkov O., Fallik E. 2002. Effect of 1-methylcyclopropene on volatile emission and aroma in cv. Anna apples. Journal of Agricultural and Food Chemistry 50: 4251-4256. DOI: $10.1021 / j f 0200873$.

Marin A.B., Colonna A.E., Kudo K., Kupferman E.M., Mattheis J.P. 2009. Measuring consumer response to 'Gala' apples treated with 1-methylcyclopropene (1-MCP). Postharvest Biology and Technology 51: 73-79. DOI: 10.1016/j.postharvbio.2008.06.008.

Milosevic N., Milosevic T., Glísic I. 2009. Productive and organoleptic traits of recent apple cultivars. Acta Horticulturae 825: 565-570. DOI: 10.17660/ActaHortic.2009.825.90.
Næs T., Brockhoff P.B., Tomic O. 2010. Statistics for sensory and consumer science. John Wiley and Sons, Ltd., p. 294.

Pre-Aymard C., Fallik E., Weksler A., Lurie S. 2005. Sensory analysis and instrumental measurements of 'Anna' apples treated with 1-methylcyclopropene. Postharvest Biology and Technology 36: 135-142. DOI: 10.1016/j.postharvbio.2004.12.007.

Raffo A., Kelderer M., Paoletti F., Zanella A. 2009. Impact of innovative controlled atmosphere storage technologies and postharvest treatments on volatile compound production in cv. Pinova apples. Journal of Agricultural and Food Chemistry 57: 915-923. DOI: $10.1021 /$ jf802054y.

Riekstiņa-Dolǵe R. 2014. Factors influencing apple cider quality. Doctoral thesis, Latvia University of Agriculture, Jelgava, Latvia, p. 156.

Rutkowski K.P., Michalczuk B., Konopacki P. 2008. Nondestructive determination of 'Golden Delicious' apple quality and harvest maturity. Journal of Fruit and Ornamental Plant Research 16: 39-52.

Sisler E.C., Dupille E., Serek M. 1996. Effect of 1methylcyclopropene and methylcyclopropene on ethylene binding and ethylene action on cut carnations. Plant Growth Regulation 18: 79-86. DOI: 10.1007/BF00028491.

Sisler E.C., Serek M. 1997. Inhibitors of ethylene responses in plants at the receptor level: recent developments. Physiologia Plantarum 100: 577-582. DOI: 10.1111/j.1399-3054.1997.tb03063.x.

Viškelis P., Rubinskienè M., Sasnauskas A., Bobinas Č., Kviklienè N. 2011. Changes in apple fruit quality during a modified atmosphere storage. Journal of Fruit and Ornamental Plant Research 19: 155-165.

Wawrzyńczak A., Jóźwiak Z.B., Rutkowski K.P. 2007. The Influence of storage conditions and 1-MCP treatment on ethylene evolution and fruit quality in 'Gala' apples. Vegetable Crops Research Bulletin 66: 188-196. DOI: 10.2478/v10032-007-0021-9. 